\title{
Effect of the Er: YAG laser on the shear bond strength of conventional glass ionomer and Biodentine $^{\mathrm{TM}}$ to dentine
}

\author{
Abtesam Aljdaimi ${ }^{1,2}$, Hugh Devlin ${ }^{1}$, Mark Dickinson ${ }^{3}$
}

Correspondence: Dr. Abtesam Aljdaimi

Email: dentistaa2017@gmail.com

\begin{abstract}
'Department of Restorative Dentistry, School of Dentistry, University of Manchester, Manchester, UK, 2Department of Restorative Dentistry, College of Dentistry, Asmarya University, Zliten, Libya, ${ }^{3}$ Department of Photon Physics, Photon Science Institute, School of Physics and Astronomy, University of Manchester, UK
\end{abstract}

\section{ABSTRACT}

Objectives: The purpose of this study was to determine if Er: YAG laser etching improves the shear bond strength (SBS) of Biodentin ${ }^{\mathrm{TM}}$ and GC Fuji IX ${ }^{\circledR}$ to dentine. Materials and Methods: Forty human dentine specimens were standardized and embedded in stone. The specimens were randomized into four groups $(n=10)$. Twenty samples were treated with the Er: YAG laser radiation and 10 of these restored with GC Fuji IX ${ }^{\circledR}$ and 10 with Biodentine ${ }^{\mathrm{TM}}$. The remaining 20 specimens acted as controls (no laser treatment); 10 were restored with GC Fuji IX ${ }^{\circledR}$ and 10 with Biodentin ${ }^{\mathrm{TM}}$. All samples were then stored in an incubator at $37.5^{\circ} \mathrm{C}$ and $100 \%$ humidity for 7 days. The SBS was determined using a Zwick universal testing machine. A two-way analysis of variance test was used to evaluate the statistical difference in SBS between the groups. An independent sample $t$-test was used to determine the statistical significance of differences between control and lased groups within the same material. Results: A highly statistically significant difference in SBS was found with the laser treatment $(P=0.0001)$ and material (i.e., Biodentin ${ }^{\mathrm{TM}}$ or Fuji IX ${ }^{\circledR}(P=0.0001)$. The GC Fuji IX ${ }^{\circledR}$ group recorded the highest mean SBS required to dislodge the material from the laser-treated dentine surface (1.77 \pm 0.22 Mega-Pascal [MPa]). The mean SBS of Biodentin ${ }^{\mathrm{TM}}$ to dentine following the laser radiation $(1.12 \pm 0.16 \mathrm{MPa})$ was significantly greater compared to the nonlased dentine $(0.53 \pm 0.09)$. Pearson Chi-square test indicated a nonsignificant relation between shear strength and mode of failure ( $P=0.467)$. Conclusion: Laser etching of the dentine surfaces yielded a significant increase in the bond strength for both GC Fuji IX ${ }^{\circledR}$ and Biodentin ${ }^{\mathrm{TM}}$. The SBS of Biodentin ${ }^{\mathrm{TM}}$ to dentine is greater than with conventional glass ionomer $\left(\mathrm{Fuji}^{\mathrm{I}} \mathrm{IX}^{\circledR}\right)$.

Key words: Biodentin ${ }^{\mathrm{TM}}$, dentin, Er: YAG laser, shear bond strength

\section{INTRODUCTION}

The proper preparation of the dentine surface before applying the restoration is an important step ensuring a good seal, decreased microleakage, a strong bond, and successful restoration. ${ }^{[1]}$ Er: YAG laser energy is well absorbed by water and hydroxyapatite, with

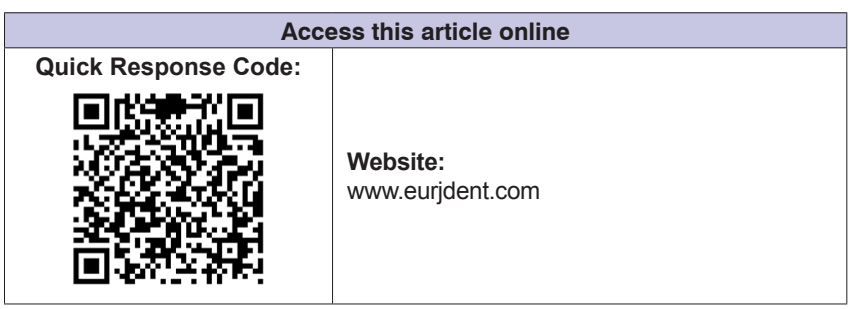

a minimal thermal impact on the tooth and the surrounding tissues, particularly when a water spray is applied. This laser tends to produce an irregular appearance of the irradiated dentine surface, and the

This is an open access journal, and articles are distributed under the terms of the Creative Commons Attribution-NonCommercial-ShareAlike 4.0 License, which allows others to remix, tweak, and build upon the work non-commercially, as long as appropriate credit is given and the new creations are licensed under the identical terms.

For reprints contact: reprints@medknow.com

How to cite this article: Aljdaimi A, Devlin H, Dickinson M. Effect of the Er: YAG laser on the shear bond strength of conventional glass ionomer and Biodentine ${ }^{\mathrm{TM}}$ to dentine. Eur J Dent 2018;12:380-5.

DOI: 10.4103/ejd.ejd_410_17 
retention of resin restorative materials has been shown to be improved. ${ }^{[2,3]}$ This study examined whether the retention of other materials (GC Fuji IX ${ }^{\circledR}$ and Biodentine $^{\mathrm{TM}}$ ) might also be improved.

Biodentine $^{\mathrm{TM}}$ and GC Fuji IX ${ }^{\mathrm{TM}}$ have different mechanisms of bonding to dentine. The adhesion of Biodentine ${ }^{\mathrm{TM}}$ to the dentinal tissue is mainly micromechanical and is not ionic-exchange based as with GC Fuji IX ${ }^{\mathrm{TM}} \cdot{ }^{[4]}$ Biodentine $^{\mathrm{TM}}$ is a calcium silicate material that is recommended as a permanent dentine restoration material. It has been described as a good dentine substitute and its easy handling properties make it a popular material among clinicians. It is a highly biocompatible material. ${ }^{[4]}$ Glass ionomer is widely employed in restorative dentistry, despite its limited adhesion to tooth structure and microleakage. ${ }^{[5,6]}$ Alternative techniques aiming to improve the adhesion of restorative materials to enamel and dentine have been suggested..$^{[7-9]}$ Er: YAG laser irradiation of dental surfaces is among those techniques. ${ }^{[10,11]}$

In an early, multicentric, randomized, prospective clinical study of Biodentine $\mathrm{T}^{\mathrm{TM}}$ as a restorative material, Koubi et al., ${ }^{[12]}$ found that Biodentin ${ }^{\mathrm{TM}}$ was able to restore posterior teeth for up to 6 months. Different results were obtained in a recent randomized control trial by Hayes et al., ${ }^{[13]}$ who found that of the 151 Biodentine ${ }^{\mathrm{TM}}$ adult root surface restorations placed, $74(52 \%)$ failed after 1 year. Most of the failures were due to a lack of restoration retention. The limited duration of the experimental period in both studies restricts the conclusions that can be made.

Our aim was to investigate whether lasing the dentine surface would increase the shear bond strength (SBS) of Biodentin ${ }^{\mathrm{TM}}$ and GC Fuji IX ${ }^{\mathrm{TM}}$, due to the increased area available for bonding to dentine. EL-Ma'aita et al. ${ }^{[14]}$ showed that removing the smear layer may have a detrimental effect. A mineral infiltration zone has been observed between the dentine and Biodentin $^{\mathrm{TM}}{ }^{[15]}$ which may be important in providing a retentive bond. This would imply that the smear layer may be critical to the formation of calcium silicate cement bonding and laser-treating the dentine, which removes this layer, may produce an unfavorable bond.

The Er: YAG laser is used successfully for the efficient removal of caries in primary teeth, with no unacceptable increase in pulpal temperature. ${ }^{[16]}$ Where pulp exposure occurs, Biodentin ${ }^{\mathrm{TM}}$ has been used to restore teeth following pulpotomy, i.e., where the contents of the pulp chamber are removed and a biocompatible material placed over the radicular pulp tissue. In such a situation, adequate stability and retention of the coronal restoration are critical to the long-term success of the pulp treatment. Similar requirements apply to Biodentine $^{\mathrm{TM}}$ repair of perforations. ${ }^{[17]}$

Therefore, our study examined whether treating dentine with the Er: YAG laser would change the adhesion of Biodentine ${ }^{\mathrm{TM}}$ and GC Fuji IX ${ }^{\circledR}$ to dentine.

\section{MATERIALS AND METHODS}

Twenty sound permanent premolar teeth were cleaned from debris and remnants of tissue using periodontal curettes and polished with a slurry of pumice and water. The teeth were stored in a $10 \%$ buffered formalin solution before the experiment under license from the Human Tissue Act, 2004 in the UK. The teeth were sectioned transversely to provide 40 dentine sections. The sections were individually embedded in stone and polished with silicon carbide paper of \#2100-grit (Buehler Ltd, Lake Bluff, IL, USA) to remove any remnant of stone on the surface and to get a perfectly flat surface. The polishing was done under continuous water cooling to avoid surface desiccation. The specimens were then randomly divided into four groups with 10 samples in each group.

- Group 1: No treatment of the dentine surface and the restorative material was GC Fuji IX ${ }^{\circledR}$

- Group 2: The moist dentine surface was irradiated with a noncontact Er: YAG laser for $30 \mathrm{~s}$, and GC Fuji IX ${ }^{\circledR}$ was used as the restorative material

- Group 3: No laser treatment of the dentine surface, and the restorative material was Biodentin ${ }^{\mathrm{TM}}$

- Group 4: Noncontact Er: YAG laser radiation was used to treat the moist dentine surface for $30 \mathrm{~s}$, and Biodentin ${ }^{\mathrm{TM}}$ was used as the restorative material.

Bisected silicon molds ( $3 \mathrm{~mm}$ diameter and $2 \mathrm{~mm}$ height) were positioned over the dentine samples and filled with GC Fuji IX ${ }^{\circledR}$ or Biodentin ${ }^{\mathrm{TM}}$, which were mixed as specified by each manufacturer. Details regarding the tested restorative materials are described in Table 1. All of the samples were stored in distilled water in an incubator at $37^{\circ} \mathrm{C}$ for 7 days to ensure full setting of the restorative materials and to ensure that the tooth and restorative materials remained fully hydrated.

\section{Laser treatment}

The Er: YAG laser was operated at $15 \mathrm{~Hz}$ and $100 \mathrm{~mJ}$, with an energy density of $8.42 \mathrm{~J} / \mathrm{cm}^{2}$. It was used to 
treat the dentine surface before the application of the restorative material. The dentine surface was continuously irrigated with water delivered across the dentine surface using a syringe with a low water flow rate. This ensured a sufficiently continuous thin water film over the dentine surface. Each dentine slab was irradiated over its entire surface.

\section{Shear bond strength test}

At the end of the storage period, the samples were mounted in the Zwick universal testing machine (Roell Z020, Zwick GmbH and Co. KG, Germany) by their metallic molds. The specimens were positioned in such a way that the stainless steel chisel of the universal testing machine was oriented perpendicularly between the tested material and tooth surface. The chisel was utilized to apply a load at a cross head speed of $0.5 \mathrm{~mm} / \mathrm{min}$ in a compression mode until debonding occurred.

The maximum fracture load in Newtons was recorded and values of SBS were calculated in Mega Pascal (MPa) according to the following equation:

Shear bond strength $=$ Fractured load $(\mathrm{N}) /$ Surface area $\left(\mathrm{mm}^{2}\right)$

The surface area (A) was calculated from the following equation:

$\mathrm{A}=\pi \mathrm{r}^{2}$

Whereas $\pi$ is 3.14 and $\mathbf{r}$ is the radius of each specimen that equals $1.5 \mathrm{~mm}$. Therefore, the surface area (A) was $7.06 \mathrm{~mm}^{2}$.

Thus, the following equation was used to convert the SBS into MPa:

$\mathrm{MPa}=$ Fractured force $(\mathrm{N}) / 7.06$

\begin{tabular}{lll}
\multicolumn{2}{l}{ Table 1: Tested restorative materials } \\
\hline Material & Manufacture & Composition \& Form \\
\hline Fuji IX GC & $\begin{array}{l}\text { GC } \\
\text { Corporation. } \\
\text { Tokyo, Japan }\end{array}$ & $\begin{array}{l}\text { Conventional glass ionomer in } \\
\text { form of powder and liquid. } \\
\text { Powder: Aluminofluorosilicate glass. } \\
\text { Liquid: } \\
\text { Polyacrylic acid, polybasic } \\
\text { carboxylic acid, water }\end{array}$ \\
Biodentine & $\begin{array}{l}\text { Septodont, } \\
\text { Saint Maur } \\
\text { Pes Fosses, }\end{array}$ & $\begin{array}{l}\text { CaColid: } \mathrm{Ca}_{3} \mathrm{SiO}_{5}, \mathrm{ZrO}_{2} \\
\text { Liquid: } \mathrm{Water}_{2} \mathrm{CaCl}_{2}, \text { partially } \\
\text { modified polycarboxylate }\end{array}$ \\
\hline
\end{tabular}

Analysis of fracture by a light microscope and scanning electron microscope

All the specimens were analyzed using a stereomicroscope at a magnification of $\times 40$ to assess the mode of failure after the bond strength test. A representative sample from each group was further investigated under the scanning electron microscope (FEI Quanta 200 ESEM).

\section{Mode of failure}

The failure was considered (i) cohesive if it occurred in the substrate or material (a visible thin coating or bulk amounts of restorative material remained on the dentine surface), (ii) adhesive when it occurred between the material and dentine, and (iii) mixed or combined if some material remained on the dentine surface.

\section{Statistical analysis}

Mean and standard deviations (SDs) were calculated, and the data were analysed by two-way analysis of variance (ANOVA), and the significance between control and lased groups within the same material was determined by the independent sample $t$-test. A Pearson Chi-squared test was applied to find the correlation between the SBS and type of failure using Statistical Package of Social Science SPSS Version 20 version 23 (IBM Corp., Armonk, US).

\section{RESULTS}

\section{Shear bond strength}

Figure 1 and Table 2 summarizes the mean values, SD, and statistical analysis of SBS for each of the experimental groups.

Two-way ANOVA showed a significant effect of the Er: YAG laser radiation and restorative material on SBS

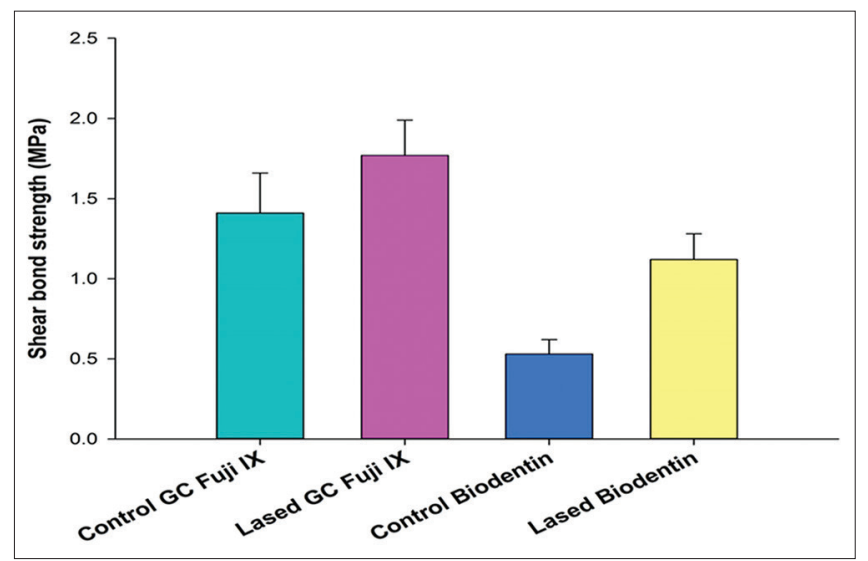

Figure 1: A bar chart illustrating the mean $(\mathrm{M})$ and standard deviation of shear bond strength megapascal for each group 
to dentine with $P=0.00001$ and 0.0001 , respectively. There was a significant difference in the SBS of laser treatment in the glass ionomer cement (GIC) group $($ mean $=1.77 \mathrm{MPa})$ compared to no laser treatment $($ mean $=1.41 \mathrm{MPa})(t$-test $=3.311, P=0.004)$. The SBS of the lased Biodentine ${ }^{\mathrm{TM}}$ group $($ mean $=1.12 \mathrm{MPa})$ was also significantly different from the nonlased Biodentin $^{\mathrm{TM}}($ mean $=0.53 \mathrm{MPa})(t$-test $=9.660$, $P=0.00001)$.

\section{Mode of failure}

The percentages of failure mode in all groups are presented in Table 3. The observation of fractured samples under the stereomicroscope microscopy showed that almost all fractures were adhesive in both GC Fuji IX ${ }^{\circledR}$ and Biodentine ${ }^{\mathrm{TM}}$ groups. The Pearson Chi-square test indicated no relation between SBS value and mode of failure $(P=0.467)$. Furthermore, there was no difference in the type of failure between the groups. Images of different failure modes under the light microscope and scanning electron microscope are presented in Figures 2-5.

\section{DISCUSSION}

In our experiments, laser pretreatment of dentine surfaces increased the bond strength significantly for both GC Fuji IX ${ }^{\circledR}$ and Biodentine ${ }^{\mathrm{TM}}$. Er: YAG laser treatment yielded a dentinal surface without a smear layer and with micro irregularities leading to a high surface wettability and producing tag formation. ${ }^{[18,19]}$ This could explain the high SBS obtained in the lased groups. The greater SBS with GC Fuji IX ${ }^{\circledR}$ than Biodentine ${ }^{\mathrm{TM}}$ might be due to differences in the mechanism of adhesion of the materials to dentine. The adhesion of GIC to dentine

\begin{tabular}{lr}
$\begin{array}{l}\text { Table } 2 \text { : Mean and standard deviation of shear bond } \\
\text { strength }(\mathrm{MPa}) \text { of all groups }\end{array}$ \\
\hline Groups & Mean \pm SD \\
\hline Control GC Fuji IX® & $1.41 \pm 0.25$ \\
Lased GC Fuji IX® $^{\mathrm{TM}}$ & $1.77 \pm 0.22$ \\
Control Biodentin $^{\mathrm{TM}}$ & $0.53 \pm 0.09$ \\
Lased Biodentin $^{\mathrm{TM}}$ & $1.12 \pm 0.16$ \\
\hline
\end{tabular}

\begin{tabular}{llccc} 
Table 3: Mode of failure of tested material \\
\hline Group & Subgroup & \multicolumn{3}{c}{ Mode of Fracture } \\
\cline { 3 - 5 } & & Adhesive & Cohesive & Mixed \\
\hline GC Fuji IX® & No laser & $(8) 80 \%$ & $(1) 10 \%$ & (1) $10 \%$ \\
& Laser treatment & $(3) 30 \%$ & (3) $30 \%$ & (4) $40 \%$ \\
Biodentin $^{\mathrm{TM}}$ & No laser & $(7) 70 \%$ & - & (3) $30 \%$ \\
& Laser treatment & (5) $50 \%$ & (3) $30 \%$ & (2) $20 \%$ \\
\hline
\end{tabular}

is mainly chemical through the ionic bonding with hydroxyapatite, ${ }^{[20]}$ whereas the Biodentine ${ }^{\mathrm{TM}}$ bonds micromechanically to dentine. ${ }^{[4]}$ Our experiments show that maintaining a smear layer is not essential for effective SBS of Biodentine ${ }^{\mathrm{TM}}$. We propose that changes in the organic and mineral content of the dentine surface produced by the laser radiation might be favorable to improve molecular interactions and increase the SBS. Supporting evidence comes from Kobayashi et al., ${ }^{[19]}$ who concluded that a high $\mathrm{Ca} / \mathrm{P}$ ratio of laser irradiated dentinal surfaces could be one reason for increased bond strength.

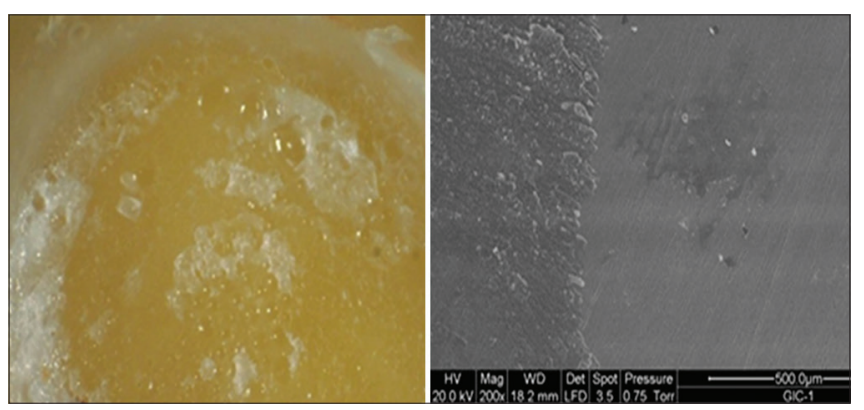

Figure 2: Stereomicroscope and scanning electron microscopy images of dentine side of the debonded specimen (GC Fuji IX) showing mixed mode of failure (some remnants of glass ionomer attached to dentine surface)

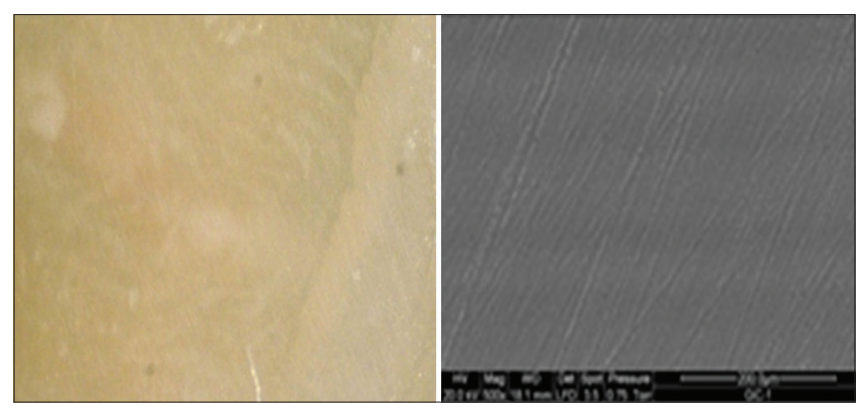

Figure 3: Stereomicroscope and scanning electron microscopy images of dentine side of debonded specimen (GC Fuji IX) showing the adhesive mode of failure (complete detachment of glass ionomer from dentine surface)

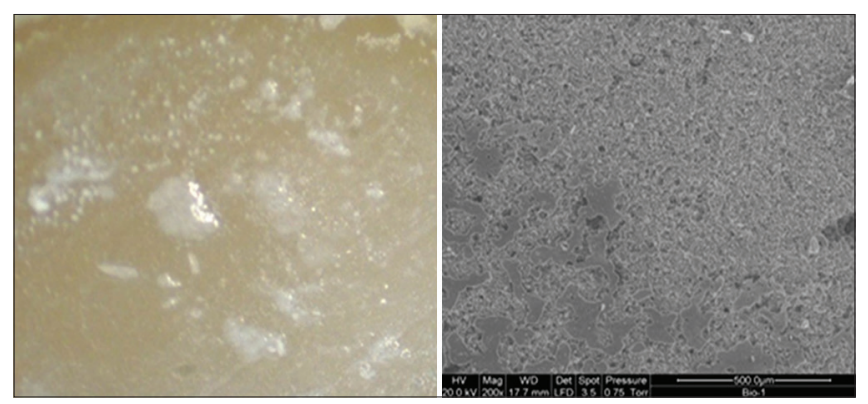

Figure 4: Stereomicroscope and scanning electron microscopy images of dentine side of debonded specimen (Biodentine) showing mixed mode of failure (some remnants of Biodentine attached to dentine surface) 


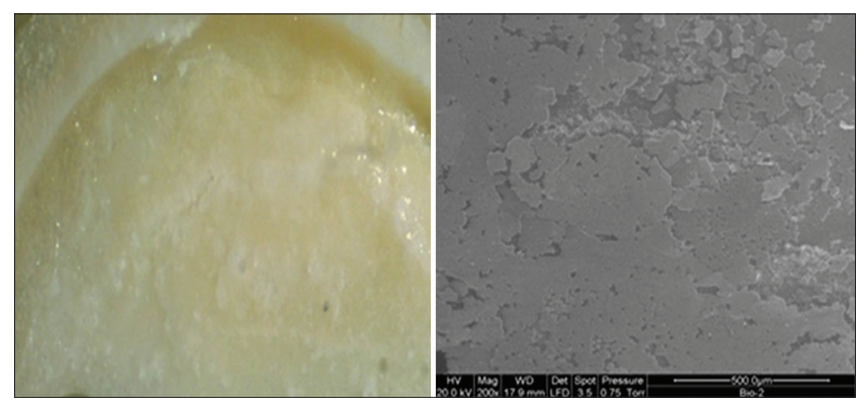

Figure 5: Stereomicroscope and scanning electron microscopy images of dentine side of debonded specimen (Biodentine) showing cohesive mode of failure (complete attachment of Biodentine to dentine)

In the literature, there are wide variations in the bond strength values produced by laser pretreatment. For instance, Kobayashi et al. ${ }^{[19]}$ used different powers of Nd: YAG laser radiation to investigate the effect of laser pretreatment on the SBS of glass ionomer to dentine. They found that at a power of $3 \mathrm{~W}$ a significant increase in the bond strength to dentine was seen, while a laser power of 1 and $2 \mathrm{~W}$ increased the bond strength but without statistical significance. In contrast, de Souza-Gabriel et al. ${ }^{[21]}$ stated that the Er: YAG laser treatment of both enamel and dentine adversely influenced the SBS of resin-modified glass ionomer to dental substrates; however, this conflicts with other results. ${ }^{[18,22]}$ Variations in the value of SBS for control GC Fuji IX ${ }^{\circledR}$ and Biodentine ${ }^{\mathrm{TM}}$ in comparison with previous studies were reported. The justification for this is mainly the different methodologies applied in each study. For instance, El Wakeel, et al. ${ }^{[23]}$ reported that the mean $\mu$ SBS of Fuji IX ${ }^{\circledR}$ was $4.82 \mathrm{MPa}$ compared to the mean SBS of $1.77 \mathrm{MPa}$ in this study. The difference might be attributed to the low-surface area used in the El Wakeel, et al. study $(0.9 \mathrm{~mm}$ in diameter and $0.7 \mathrm{~mm}$ in height) compared to the area $(3 \mathrm{~mm} \times 3 \mathrm{~mm})$ in our study, as aforementioned, the SBS is calculated according to the following equation:

Shear bond strength $=$ Fractured load $(\mathrm{N}) /$ Surface area $\left(\mathrm{mm}^{2}\right)$

The timeframe through which the SBS is evaluated is a significant consideration. ${ }^{[2]}$ The storage period of this study was 7 days whereas that of El Wakeel et al.'s study ${ }^{[23]}$ was $24 \mathrm{~h}$ where setting may have been incomplete. Following $24 \mathrm{~h}$ of storage, the glass ionomer maturation may be incomplete resulting in a low value of bond strength. ${ }^{[25]}$ This was confirmed by Choudhari, ${ }^{[26]}$ who stated that the initial adhesion between glass ionomer, and tooth is based on hydrogen bonding that matures and evolves to a stronger chemical bond over time. Nevertheless, the results of the present study regarding Biodentine ${ }^{\mathrm{TM}}$ are in the same range as that of some other studies. ${ }^{[27]}$

The adhesive mode of failure was predominately observed among all the tested groups, with a few samples exhibiting a mixed and cohesive failure pattern. Similar results have been reported with previous studies. ${ }^{[19,28,29]}$ However, some studies reported cohesive failure as the main mode of fracture. ${ }^{[27,30,31]}$ The presence of a mixed failure could be attributed to various factors such as the low wear resistance of glass ionomer, the formation of a matrix layer, and the chemical bonding of GIC to the tooth. ${ }^{[30]}$ The high incidence of adhesive failure indicates that a more uniform distribution of stress existed along the bonded assembly. ${ }^{[32,33]}$ In the present study, no direct relationship between the value of bond strength and the mode of failure was observed. However, direct comparison of the present data of SBS with values of previous studies might only be possible if the materials were tested utilizing the same conditions. ${ }^{[34]}$

It is important to state that the water storage media of specimens throughout the experiment may affect the validity of the results. In vivo the dentinal tubules are mainly occupied with fluid and odontoblastic processes, thus the utilization of water as a means of storage may have changed the dentine permeability leading to possible differences between in vivo and in vitro findings. ${ }^{[35]}$ A lack of dentine vitality in in vitro experiments might limit the possibility of extrapolating these data to in vivo conditions. ${ }^{[30]}$ Moreover, the test of bond strength was not done immediately after the initial setting, whereas in the real clinical situation, the restored teeth are exposed to masticatory load immediately. It is assumed that other variations between the groups such as due to storage of the specimens were accounted for since all the teeth of all groups were treated in the same way except for the experimental manipulation.

\section{CONCLUSION}

It can be concluded that lasing the dentine with an Er: YAG laser improved the mean SBS of both GC Fuji IX ${ }^{\circledR}$ and Biodentine ${ }^{\mathrm{TM}}$. In the case of Biodentine, this was approximately doubled following the laser treatment. Er: YAG laser irradiation produced surface properties that enhanced the adhesion of restorative materials to dentine. However, GC Fuji IX ${ }^{\circledR}$ has a stronger bond strength to dentine than Biodentine ${ }^{\mathrm{TM}}$ due to chemical and mechanical interactions between dentine and GC Fuji IX. 


\section{Acknowledgment}

The authors would like to thank Mr. Patrick Hill for helping in the imaging of failure type under the scanning electron microscope. We also thank Dr. Tanya Walsh for her valuable advice on the statistical analysis of the data.

\section{Financial support and sponsorship Nil.}

\section{Conflicts of interest}

There are no conflicts of interest.

\section{REFERENCES}

1. Shahabi S, Chiniforoush N, Fekrazad R, Fatemi SM. Comparison of tensile bond strength of composite to dentin in conventional or laser-prepared Cavities (Er; Cr: YSGG). J Oral Laser Appl 2010;10:107.

2. Hossain M, Nakamura Y, Yamada Y, Kimura Y, Nakamura G, Matsumoto K. Ablation depths and morphological changes in human enamel and dentin after Er: YAG laser irradiation with or without water mist. J Clin Laser Med Surg 1999;17:105-9.

3. Najeeb S, Khurshid Z, Zafar MS, Ajlal S. Applications of light amplification by stimulated emission of radiation (Lasers) for restorative dentistry. Med Princ Pract 2016;25:201-11.

4. Gjorgievska ES, Nicholson JW, Apostolska SM, Coleman NJ, Booth SE, Slipper IJ, et al. Interfacial properties of three different bioactive dentine substitutes. Microsc Microanal 2013;19:1450-7.

5. Rekha CV, Balagopal Varma J. Comparative evaluation of tensile bond strength and microleakage of conventional glass ionomer cement, resin modified glass ionomer cement and compomer: An in vitro study. Contemp Clin Dent 2012;3:282-7.

6. Raju VG, Venumbaka NR, Mungara J, Vijayakumar P, Rajendran S, Elangovan $\mathrm{A}$, et al. Comparative evaluation of shear bond strength and microleakage of tricalcium silicate-based restorative material and radioopaque posterior glass ionomer restorative cement in primary and permanent teeth: An in vitro study. J Indian Soc Pedod Prev Dent 2014;32:304-10.

7. Cooper LF, Myers ML, Nelson DG, Mowery AS. Shear strength of composite bonded to laser-pretreated dentin. J Prosthet Dent 1988;60:45-9.

8. Markovic D, Petrovic B, Peric T, Miletic I, Andjelkovic S. The impact of fissure depth and enamel conditioning protocols on glass-ionomer and resin-based fissure sealant penetration. J Adhes Dent 2011;13:171-8.

9. Martínez-Insua A, Da Silva Dominguez L, Rivera FG, Santana-Penín UA. Differences in bonding to acid-etched or Er: YAG-laser-treated enamel and dentin surfaces. J Prosthet Dent 2000;84:280-8

10. Ceballo L, Toledano M, Osorio R, Tay FR, Marshall GW. Bonding to Er-YAG-laser-treated dentin. J Dent Res 2002;81:119-22.

11. Souza-Gabriel AE, Chinelatti MA, Borsatto MC, Pécora JD, Palma-Dibb RG, Corona SA, et al. SEM analysis of enamel surface treated by Er: YAG laser: Influence of irradiation distance. Microsc Res Tech 2008;71:536-41.

12. Koubi G, Colon P, Franquin JC, Hartmann A, Richard G, Faure MO, et al. Clinical evaluation of the performance and safety of a new dentine substitute, biodentine, in the restoration of posterior teeth $-\mathrm{A}$ prospective study. Clin Oral Investig 2013;17:243-9.

13. Hayes M, da Mata C, Tada S, Cole M, McKenna G, Burke FM, et al. Evaluation of biodentine in the restoration of root caries: A randomized controlled trial. JDR Clini Transl Res 2016;1:51-8.

14. El-Ma'aita AM, Qualtrough AJ, Watts DC. The effect of smear layer on the push-out bond strength of root canal calcium silicate cements. Dent Mater 2013;29:797-803.

15. Atmeh AR, Chong EZ, Richard G, Festy F, Watson TF. Dentin-cement interfacial interaction: Calcium silicates and polyalkenoates. J Dent Res 2012;91:454-9.

16. Al-Batayneh OB, Seow WK, Walsh LJ. Assessment of Er: YAG laser for cavity preparation in primary and permanent teeth: A scanning electron microscopy and thermographic study. Pediatr Dent 2014;36:90-4.

17. Hashem DF. Calcium Silicate Cements used as a Therapeutic Dentine Replacement: In vitro and in vivo Studies. King's College London; 2015.

18. Türkmen C, Sazak-Oveçoğlu H, Günday M, Güngör G, Durkan M, Oksüz M, et al. Shear bond strength of composite bonded with three adhesives to Er, Cr: YSGG laser-prepared enamel. Quintessence Int 2010;41:e119-24.

19. Kobayashi CA, Fujishima A, Miyazaki T, Kimura Y, Matsumoto K, Osada T, et al. Effect of Nd: YAG laser irradiation on shear bond strength of glass-lonomer luting cement to dentin surface. Int J Prosthodont 2003;16:493-8.

20. Wilson AD, McLean JW. Glass-Ionomer Cement. Chicago: Quintessence Pub Co.; 1988.

21. de Souza-Gabriel AE, do Amaral FL, Pécora JD, Palma-Dibb RG, Corona SA. Shear bond strength of resin-modified glass ionomer cements to Er: YAG laser-treated tooth structure. Oper Dent 2006;31:212-8.

22. Jafari A, Shahabi S, Chiniforush N, Shariat A. Comparison of the shear bond strength of resin modified glass ionomer to enamel in bur-prepared or lased teeth (Er: YAG). J Dent (Tehran) 2013;10:119-23.

23. El Wakeel AM, Elkassas DW, Yousry MM. Bonding of contemporary glass ionomer cements to different tooth substrates; microshear bond strength and scanning electron microscope study. Eur J Dent 2015;9:176-82.

24. Yesilyurt C, Bulucu B, Sezen O, Bulut G, Celik D. Bond strengths of two conventional glass-ionomer cements to irradiated and non-irradiated dentin. Dent Mater J 2008;27:695-701.

25. Shebl EA, Etman WM, Genaid TM, Shalaby ME. Durability of bond strength of glass-ionomers to enamel. Tanta Dent J 2015;12:16-27.

26. Choudhari S. Clinical evaluation of efficacy of three restorative materials in primary teeth-Six month follow up study. Int J Clin Dent Sci 2011;1:45-52.

27. Kaup M, Dammann CH, Schäfer E, Dammaschke T. Shear bond strength of biodentine, proRoot MTA, glass ionomer cement and composite resin on human dentine ex vivo. Head Face Med 2015;11:14.

28. Wang L, Sakai VT, Kawai ES, Buzalaf MA, Atta MT. Effect of adhesive systems associated with resin-modified glass ionomer cements. J Oral Rehabil 2006;33:110-6.

29. Friedl KH, Powers JM, Hiller KA. Influence of different factors on bond strength of hybrid ionomers. Oper Dent 1995;20:74-80.

30. Carvalho TS, van Amerongen WE, de Gee A, Bönecker M, Sampaio FC Shear bond strengths of three glass ionomer cements to enamel and dentine. Med Oral Patol Oral Cir Bucal 2011;16:e406-10.

31. Nujella BP, Choudary MT, Reddy SP, Kumar MK, Gopal T. Comparison of shear bond strength of aesthetic restorative materials. Contemp Clin Dent 2012;3:22-6.

32. Armstrong SR, Boyer DB, Keller JC. Microtensile bond strength testing and failure analysis of two dentin adhesives. Dent Mater 1998;14:44-50.

33. Yip HK, Tay FR, Ngo HC, Smales RJ, Pashley DH. Bonding of contemporary glass ionomer cements to dentin. Dent Mater 2001;17:456-70

34. Sudsangiam S, van Noort R. Do dentin bond strength tests serve a useful purpose? J Adhes Dent 1999;1:57-67.

35. Ozok AR, Wu MK, Ten Cate JM, Wesselink PR. Effect of dentinal fluid composition on dentin demineralization in vitro. J Dent Res 2004;83:849-53. 